AperTO - Archivio Istituzionale Open Access dell'Università di Torino

\title{
Explaining why, right or wrong, (Italian) households do not like reverse mortgages
}

\section{This is a pre print version of the following article:}

Original Citation:

\section{Availability:}

This version is available http://hdl.handle.net/2318/1558645

since 2016-03-24T11:45:53Z

Published version:

DOI:10.1017/S1474747215000013

Terms of use:

Open Access

Anyone can freely access the full text of works made available as "Open Access". Works made available under a Creative Commons license can be used according to the terms and conditions of said license. Use of all other works requires consent of the right holder (author or publisher) if not exempted from copyright protection by the applicable law. 


\title{
Explaining why, right or wrong, (Italian) households do not like reverse mortgages
}

\author{
Elsa Fornero* \\ Mariacristina Rossi \\ Maria Cesira Urzì Brancati*
}

\begin{abstract}
According to economic theory, elderly homeowners should be much more eager than they actually are to adopt financial instruments allowing them to borrow against home equity. This paper investigates the determinants of interest in one such instrument: the reverse mortgage. Our focus is the Italian market and we draw from a unique dataset, UniCredit's 2007 survey on household savings to perform our empirical analysis. Out of over 1,200 respondents, roughly $60 \%$ claimed to have no interest in the product, while the remaining $40 \%$ expressed various degrees of appeal, from quite low to very high. Risk/uncertainty related elements are strongly correlated with interest in the product. Willingness to sell one's home (as a means to increase future income) and uncertainty about post-retirement standard of living are significant predictors of high interest in the product, while an aversion to take on debt and a larger housing equity predict a lack of interest. This results suggest that reverse mortgages are not perceived as instruments to accomplish a better standard of living in old age, but rather as a last resort choice in case of necessity.
\end{abstract}

Keywords: reverse mortgage, annuity, elderly welfare, housing, lifecycle.

J.E.L. classification: G11, J14, I13

\footnotetext{
We wish to thank Giancarlo Marini, Riccardo Calcagno, Chiara Monticone, Flavia Coda-Moscarola and the participants to the XX Tor Vergata International Conference on Money, Banking and Finance, the Netspar International Pension Workshop 2012 and the SAVE-PHF conference 2012 for the helpful comments; we thank Dimitris Christelis for the useful discussion. We are also grateful to Collegio Carlo Alberto and Netspar for funding, and to UniCredit for the data.

${ }^{*}$ University of Turin, CeRP-Collegio Carlo Alberto, and Netspar, (elsa.fornero@unito.it, http://web.econ.unito.it/fornero/)

- University of Turin and CeRP-Collegio Carlo Alberto (rossi@econ.unito.it)

- University of Tor Vergata and CeRP-Collegio Carlo Alberto.

Correspondence author: Via Real Collegio 30 - 10024 Moncalieri (TO) Italy.

Tel +39011 6705040;

Fax +39011 6705042;

Email: cesira.urzi@carloalberto.org
} 


\section{Introduction}

As western societies experienced unprecedented population ageing, the saving behaviour of the elderly and their portfolio holdings has become central to the policy debate; dependency ratios will rise dramatically over the next 30 years, especially for Italy, France, Germany and Japan where they are projected to exceed 45 percent by 2050 (Mitchell and Piggott, 2003). The effects of the demographic trends are massive, even more so in countries where the elderly are heavily dependent on publicly provided income and benefit programs. Unless the elderly are able to finance a consistent share of their expenditure through accumulated assets, the sustainability of national welfare systems will be undermined, and because real rather than financial assets are predominant in households' portfolios, the availability of financial instruments designed to help decumulate illiquid assets is crucial. Among such instruments, reverse mortgage loans (RMs) stand out because they allow better consumption smoothing in old age. At the same time, by encouraging the direct participation of the elderly in financing their retirement needs, RMs could ease the burden of ageing on public budgets.

Despite their welfare-improving potential, RMs have received only limited acceptance (Caplin 2001) and many explanations have arisen to explain it. First of all, it is not just illiquid assets, but all assets that elderly households seem reluctant to shed. While according to Modigliani and Bruemberg's (1954) lifecycle hypothesis, individuals smooth their lifetime consumption by borrowing when 'young', saving when 'middle aged', and dissaving when 'old', empirically the rate of wealth decumulation appears slower than the model predicts (Venti and Wise 1987; Ando et al.1993; Chiuri and Jappelli 2007; Angelini and Laferrère 2010), with precautionary savings motivated by 
expected health and care expenditures (Carroll et al. 1992) and bequest motives (Kotlikoff and Summers 1981) or a combination of both (Skinner and Zeldes, 2002) explaining discrepancies between facts and theory.

The portfolio composition of the elderly, which generally favours illiquid assets such as housing (Mitchell and Piggott 2003), can be a further disincentive to asset depletion. Housing equity can be liquidated by selling one's home and renting, or moving to a smaller dwelling (downsizing), however, this involves both financial and psychological transaction costs (Leviton 2002), so the elderly may prefer to settle for lower consumption levels. RMs represent a feasible solution to eschew undesired consumption drops when old.

Because of its swift population ageing and high homeownership rates $(78 \%$ among the elderly), Italy is an interesting case for studying households' attitudes toward RMs. Drawing on a unique dataset, the 2007 UniCredit Survey (UCS), in which over 1,200 respondents indicated their interest in taking out such a loan (with $40 \%$ expressing various degrees of appeal), we investigate the underlying factors determining interest in the product with the use of a discrete choice model. We find that risk/uncertainty-related elements are significantly correlated with interest in the product, while the bequest motive, proxied by having children in the household, does not preclude interest in the product ${ }^{1}$. Respondents who have negative expectations on public pensions, that is express concern about their standard of living after retirement, are significantly more likely to be interested. Finally, higher levels of financial literacy appear to have a negative effect, but the results are barely significant.

\footnotetext{
${ }^{1}$ RMs can be used to give financial help children and grandchildren while one is still alive.
} 
The remainder of the paper is organized as follows: Section 1 describes the main features of RMs. Section 2 reviews the relevant literature. Section 3 calculates the net worth of RMs and provides clues on their potential market size. Section 4 introduces the data sources and explains how the main indicators are constructed. Section 5 describes the econometric model and presents the estimated results. Section 6 concludes the paper.

\section{RMs: An overview}

RMs are innovative financial products because they allow elderly homeowners to consume (part of) their housing equity without having to disrupt housing arrangements, and without any obligation of repayment until the borrower dies, moves out, or sells the house (Eschtruth and Tran 2001). They differ from home reversion programs (such as the sale of bare ownership) in that the property rights over the house remain with the borrower, while with home reversion programs the property rights are transferred onto the lender, the borrower only retaining the right to live in the estate until death (usufruct) $)^{2}$.

The loan can be paid out as a lump sum, through fixed monthly payments (term, tenure plan or life annuity), as a line of credit, or as a combination of term / tenure plan and line of credit (Rodda et al.).

The amount of the loan depends positively on the age of the (youngest in a couple) borrower and the value of the property and negatively on the interest rate. The outstanding balance of the loan grows over time, as the interest is capitalised, but no payment is due until the borrower (or spouse)

\footnotetext{
2 The difference is about who benefits from a housing market upturn: by entering a home reversion scheme, the borrower gives up any claim on future house value appreciation; conversely, by taking out a reverse mortgage, any appreciation of the value of the house will benefit the borrower or the borrower's heirs.
} 
dies, moves out, or sells the house. When any of these events occurs, the loan must be repaid in full - in one solution within the subsequent 10 to 12 months - and with any available source of funds, including proceeds from the sale of the house (Eschtruth and Tran 2001); thus borrowers (or their heirs) have the choice to either pay back the loan and keep the house, or sell the house to repay the loan and cash the difference (if any). RMs provide a series of safeguards and advantages for the borrowers and their heirs: should the amount withdrawn exceed the value of the house once it's sold, borrowers (or their heirs) do not have to pay the difference (Rodda et al.).

Despite these attractive features, RMs have not (yet?) gained the favour of elderly homeowners. Introduced by US Congress in 1987 explicitly to facilitate the financing of consumption in old age (Rodda et al. 2000), Home Equity Conversion Mortgages (HECMs) are still rather uncommon, even in the US, since not even $1 \%$ of possible beneficiaries has entered an equity release scheme (Caplin 2001). The trend, however, seems to have changed in recent years (at least up to the 2008 financial crisis), the market size of HECMs more than decoupling: Shan's (2009) report to the US Federal Reserve Board of Governors shows that the number of RM loans escalated from less than 10,000 in 2001 to over 100,000 in 2007 and mentions rising home values, lower interest rates, and increasing awareness of the product as plausible explanatory factors (we do not have evidence following the bursting of the housing bubble).

The European Union (EU) RM market is not only very thin, but also unevenly developed across countries with regards to volume of production, 
lending methods, and diversity of products. ${ }^{3}$ Most equity release schemes in the EU share common criteria, in terms of minimum age requirements and minimum property value (which must be free from other debt), and involve a series of protections for borrowers, as well as the obligation to carry out repairs and maintenance. Borrowers are protected from declining home prices because the value of the loan cannot exceed the value of the house (no negative equity guarantee); conversely, if the house is sold for more than the loan is worth, the excess equity belongs to the heirs.

As many as 13 EU countries have at least one institution supplying some form of equity release product ${ }^{4}$, with Ireland, Spain, and the UK totalling the highest numbers of providers. The estimated number of equity release contracts sold in 2007 in the UK was 33,000, versus 3,600 in Spain, 2,500 in Sweden, 300 in Italy, 200 in France, and 100 in Germany ${ }^{5}$ (data for Ireland were not available). The UK has a long history of home reversion plans, dating as far back as $1965^{6}$; however, according to a report from the Council of Mortgage Lenders (CML), despite a recent upward trend, the market has remained substantially underdeveloped and stagnant (Williams, 2008). The CML report suggests that negative reputation of earlier generation equity release products and perceived excessive costs are the main reasons for the underdevelopment of their market. Indeed, as the housing price appreciation of the 1980s failed to match the accrued interest on mortgages, borrowers

\footnotetext{
${ }^{3}$ According to the Study on Equity Release Schemes in the EU, commissioned by the EU and carried out by the Institut für Finanzdienstleistungen (IFF) in 2007 (available at http://ec.europa.eu/internal market/finservicesretail/docs/credit/equity release part1 en.pdf), approximately 45,000 lifetime/reverse mortgages contracts were signed in the EU in 2007, for an estimated value of $€ 3.3$ billion, less than $0.1 \%$ of the overall mortgage market. ${ }^{4}$ Austria, Bulgaria, Czech Republic, Finland, France, Germany, Hungary, Ireland, Italy, the Netherlands, Poland, Romania, Spain, Sweden, and the UK.

${ }^{5}$ Data from the Study on Equity Release Schemes, 2007, and responses from providers and regulators, with IFF calculations.

${ }^{6}$ The first reversion income scheme was introduced by Home Reversions in 1965; the first home income plan based on a mortgage and annuity was issued in 1972. Cash reversion plans were introduced in 1978 by JG Inskip \& Co. (Joseph Rountree Foundation 2003).
} 
found themselves owing more than their property was worth and this raised the concern for a no negative equity guarantee.

In Italy, the product was formally introduced in 2005 under the name prestito vitalizio ipotecario available to homeowners over 65 whose housing equity exceeds $€ 70,000$. So far, only a few credit institutions offer home equity conversion products: Deutsche Bank's PatrimonioCasa ${ }^{7}$ and Euvis's Prestito Vitalizio are available only as a lump sum, while Banca Monte dei Paschi di Siena offers PrestiSenior ${ }^{8}$ to those over 70 as either a lump sum or an annuity for a maximum of 20 years.

According to Case and Schnare (1994), interest in RMs should be strong among the 'house-rich, cash-poor' (pp. 301) elderly homeowners, and, since such description fits more than 3 million Americans, they estimate a large potential market. Mayer and Simons (1993) also note the high poverty alleviating potential of RMs, since many elderly could use them to pay off pre-existing debts. Ong (2008) estimates that RMs could lift out of poverty 95\% of income-poor elderly Australians, and identifies single women aged 80 and over as the segment of the population that would benefit the most. Conversely, empirical studies carried out in the US (Venti and Wise, 1987) and the UK (Hancook, 1998) see a more limited scope for RMs, claiming that low-income elderly generally have little, if any, housing equity available. Caplin (2001) suggests that, even with the most pessimistic assessments, the RMs market should be much larger than it is, and highlights transactions costs, moral hazard, and uncertainty about future needs and preferences as the main economic forces that hinder its development. Mitchell and Piggott

\footnotetext{
${ }^{7}$ Deutsche Bank (2010), informational pamphlet for the prestito vitalizio ipotecario PatrimonioCasa contract.

${ }^{8}$ Montepaschi, informational pamphlet for the prestito vitalizio ipotecario PrestiSenior, April 2011.
} 
(2003) suggest that before a RMs market can established (in Japan), governments need to address relatively underdeveloped financial markets and regulatory infrastructure.

To explain why the market is so thin, other researchers focus on the high costs of RMs. For example, the possibility of moral hazard in the case of meagre home maintenance by homeowners intending to default on their contract obligations $^{9}$ (Caplin 2000) and the adverse selection of longer-lived mortgagors $^{10}$ (Davidoff and Welke 2005) can translate into high insurance fees and make the product rather expensive. Leviton (2002) also mentions that taking out a RM conflicted with the desire to leave a legacy, however, other studies reported that many elderly would use the RM annuity to help their children (Rodda et al. 2000).

Gibler and Rabianski (1993) mention debt aversion among the elderly as a barrier to the uptake of RMs. The authors report that older consumers generally dislike buying on credit and would rather live on less income than take out a loan. Caplin (2000) also suggests that households may prefer a lower level of consumption in a debt-free house to a higher level in a debtridden one, relating the presence of debt with an increase in uncertainty. Finally, Shan (2009) indicates that an increased tendency to take on debt over the past few years can explain part of the substantial growth of the US RM market.

\footnotetext{
${ }^{9}$ Caplin (2000) emphasises moral hazard in home maintenance and argues that, since typical RM borrowers are very old, very poor, and likely to suffer from health problems, they are also more likely to let their properties deteriorate, and thus the legal provisions protecting the lender may not be enforced. The author advocates a rationalisation of the regulatory system as a means of fostering financial innovation in general and promoting RMs in particular. ${ }^{10}$ Davidoff and Welke (2005) investigate adverse selection by comparing the mobility rates between RM borrowers and non- borrowers. Interestingly, the authors reveal advantageous selection, since homeowners who take out RMs are also more likely to sell their homes and therefore repay their loans earlier.
} 
Another possible explanation for the limited interest in RMs may be financial illiteracy. ${ }^{11}$ Gibler and Rabiansky (1993) differentiate between financially sophisticated homeowners, who may see RMs as part of an investment portfolio decision, and financially unsophisticated ones, who are less likely to be interested in a product that is both unknown and complex. Leviton (2002), for example, explains how, because of poor financial education, many elderly homeowners overestimated the net worth of their RMs and felt disappointed when given the real figures by mortgage counsellors. Reed (2009) finds that, among Australian homeowners who claimed to be aware of RMs, only $40 \%$ understood the basic features, specifically, that no repayments were due and that the house would not be sold. Duca and Kumar (2010) also report a positive correlation between households with mortgage equity withdrawals and lack of financial literacy. Finally, Fornero and Monticone (2011) relate financial literacy with effective retirement planning and report that most Italians lack knowledge of basic financial concepts. It is also worth noting that the US law establishes that borrowers obtain financial counselling before they can apply for a HECM loan (Rodda et al. 2000), while, to our knowledge, this is not yet the case in Europe.

\section{Estimating the monetary value of RMs}

Our analysis cannot directly estimate the impact of RMs uptake on the welfare of the elderly, as we do not have the relevant data; we can, however, calculate RMs money's worth and appraise the potential benefits as a

\footnotetext{
${ }^{11}$ Lusardi and Mitchell (2006) define financial literacy as a set of tools enabling one to better allocate financial resources; it is often associated with numerical skills, such as the ability to calculate rates of return on investments and the interest rate on debt, or understanding economic concepts such as the trade-off between risk and return, the benefits of diversification, and the benefits and risks associated with specific financial decisions.
} 
percentage increase in income for given demographics and housing equity levels in the UCS.

We adopt the sinking fund formula used in Ong (2008), based on the Evaluation Report of FHA's ${ }^{12}$ Home Equity Conversion Mortgage Insurance Demonstration by Rodda et al. (2000). The formula yields the payments generated by RMs for a given housing equity level, interest rate, and life expectancy.

Payments to borrowers are calculated according to the principal limit factor, ${ }^{13}$ the age (or life expectancy) of the (youngest, in a couple) borrower, the mortgage interest rate, and the adjusted property value. As for our calculations (reported in Table 2), the principal limit factor in Italy ranges from roughly $20 \%$ of the housing equity for 65 -years-olds to roughly $50 \%$ for those over $90^{14}$; the borrower's life expectancy (in months) is set at 100 minus the current age, multiplied by 12 (Rodda et al. 2000); the interest rate is set at $6.8 \%$ per annum $(0.55 \%$ per month), an average of the Deutsche Bank (7.3\%), ${ }^{15}$ Monte dei Paschi di Siena (7.9\%), and the Housing and Urban Development's HECM (5.5\%) RM rates; the average housing equity is calculated from our sample homeowners.

The yearly payment to the borrower under the tenure plan can be computed as an annuity, using the formula

$$
A_{i}=H \frac{r}{(1+r)^{e_{i}+1}-(1+r)}
$$

\footnotetext{
${ }^{12}$ Federal housing association.

${ }^{13}$ The principal limit is computed so that the expected mortgage insurance losses over the life of the loan are no greater than the expected premium collected. The higher the expected interest rates, the lower the principal limit factor: Higher expected interest rates mean higher future loan balances, which would result in larger insurance losses unless the amount of principal advanced were reduced.

${ }^{14}$ The values reported are for single male householders; the corresponding percentages for single females are $15.3 \%$ for 65 -year-olds to $46 \%$ for those over 90 . The maximum loan amount for couples is lower (14-45\%).

${ }^{15}$ From the Deutsche Bank's informative leaflet for Italian reverse mortgage borrowers.
} 
where

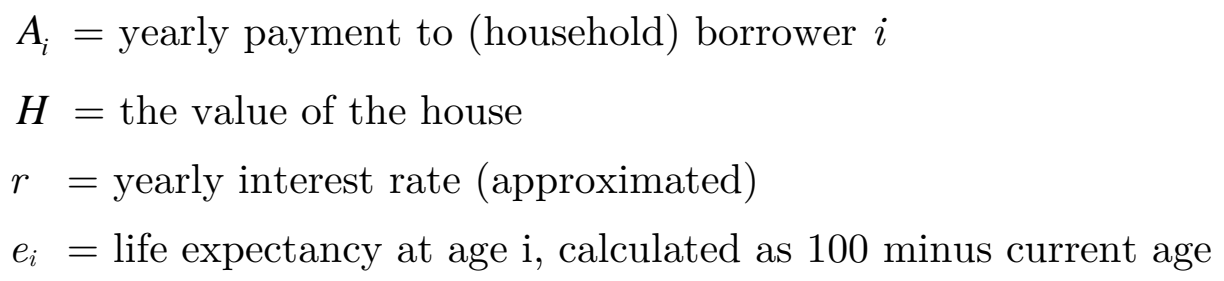

Table 2 describes the results of our calculations for the UCS sample, restricted to the over 65 . The first column reports estimates of the average housing equity by housing quintile, age, household income units, and geographical area. The second column shows the maximum loan advance, calculated as housing equity ${ }^{16}$ multiplied by the percentage available to the average age group for each subcategory. The third column reports the annuity, calculated by applying the sinking fund formula (times 12, since the formula refers to a monthly sum). The fourth column shows the estimated average income for the categories reported above and the last column calculates the RM as a percentage of income. The results are qualitatively similar to those reported by Ong (2008), since those over 75 and single females with lower incomes and above average housing equity would benefit the most from taking our a RM.

\section{Empirical analysis}

\subsection{Data}

Our analysis draws from a unique source of data, the UCS, carried out in 2007. The survey targets the bank's clients aged $21-75$ with at least $€ 10,000$ in deposits. The sample is stratified according to geographical area, city size, and financial wealth. Additional data were extracted from the Bank of Italy's

\footnotetext{
${ }^{16}$ Average values are reported.
} 
2006 Survey of Household Income and Wealth (SHIW) to compare the characteristics of UCS respondents with those of a representative sample of the entire Italian population (see Table 3).

As well as collecting detailed demographic and financial data for a sample of 1,686 individuals, the survey directly elicits respondents' interest in RMs. The question is asked to the household head, i.e. the person responsible for financial decisions, if he or she is a homeowner. A brief description of the product was given by the interviewer, and respondents assigned a value between 1 and 5 according to their level of interest: 1.1\% claimed to be 'very interested', $6.2 \%$ 'quite interested', $12.9 \%$ 'somewhat interested', $20.4 \%$ 'barely interested', and 59.4 'not interested'.

The UCS oversamples the wealthy (see Table 4): the average household income in the UCS is $€ 71,325$ (median $€ 48,393$ ), roughly 2.2 times the average SHIW household income of $€ 31,893$ (median $€ 26,217$ ). Households are categorised according to their wealth bracket, defined by the amount of money kept in UniCredit deposits, ranging from $€ 10,000$ to $€ 5$ million. While the average financial wealth in the SHIW amounts to $€ 25,246$ (median $€ 6,674)$, with $18 \%$ of households reporting no financial wealth at all, the average wealth bracket in the UCS is $€ 100,000$ to $€ 150,000$. The rate of homeownership is also substantially higher: approximately $90 \%$ of the UCS households own their home, versus $71 \%$ in the SHIW, and the rates of homeownership among the elderly are even higher, $93 \%$ in the UCS versus $78 \%$ in the SHIW. As for housing equity, Table 5 shows how the average house value in the UCS is 1.8 times that in the SHIW, with a mean value of 
$€ 376,613^{17}$. Finally, educational attainment is higher in the UCS: the percentage of respondents who have at least an upper secondary certification is more than double that for the $\mathrm{SHIW}^{18}$ (see Table 3). Elderly male household heads are on average wealthier both in terms of housing value and in terms of household income (Table 7).

The trade-off between risk and return on investments reveals a majority of moderately risk-averse respondents ${ }^{19}$. Another set of risk-related questions investigates the respondents' risk attitude in a context of gain or loss (questions in appendix) ${ }^{20}$. Both elderly male and female household heads are more risk averse than their younger counterpart in a gain scenario, while women under 65 years of age are the most risk loving, particularly in a loss scenario. Expectations on future public pensions is ascertained by asking respondents how worried they felt about their standard of living after retirement, with nearly $40 \%$ answering 'quite worried' or 'very worried'.

Over $85 \%$ of respondents consider not having future debts an important reason for saving, and over $70.5 \%$ are averse to debt. When asked how they would finance a hypothetical expenditure of $€ 20,000$, more than $60 \%$ replied they would draw from their savings, $20 \%$ would sell their financial assets, and about $16 \%$ would take out a bank loan. One question was specifically asked to assess respondents' willingness to sell their home as a means of increasing future income: the idea that the elderly do not wish to downsize appears to

\footnotetext{
17 The data regarding housing equity had to be cleaned substantially, since a few hundred respondents provided implausible numbers (writing 1s, 999s or over a hundred millions); the first decile and the top percentile had to be trimmed to yield these values.

${ }^{18}$ However, Banca d'Italia's official 2008 Report on Household Wealth specifies that the sample is affected by selection bias, as in the lower participation of wealthier households and under-reporting of income and wealth. ${ }^{19}$ Only $1.8 \%$ would rather have high returns and high risks; $27.6 \%$ prefer good returns and sufficient safety; $52 \%$ prefer sufficient returns and good safety, and $18.6 \%$ prefer low returns but no risks.

${ }^{20}$ Kahneman and Tversky (1991) define framing as the way in which a choice or an option can be affected by the way it is presented to a decision maker, specifically whether it is presented as a gain or as a loss; individuals are generally found to be more risk averse if the question is framed as a gain, and more risk loving if framed as a loss.
} 
be confirmed by the high proportion answering 'certainly not' (53.1\%) or 'probably not' (27.0\%).

The respondents' financial literacy (questions in appendix) was gauged by only three of the four questions about inflation, interest rates, and portfolio diversification, in order to have an indicator which is more consistent with the one used by Lusardi and Mitchell. We did not use the self assessed index as it is more an indicator of overconfidence than actual financial knowledge (Guiso and Jappelli 2009). Less than $8 \%$ of the respondents answered at all three questions correctly, with elderly female household heads exhibiting overall worse performance (see Table 6).

A preliminary descriptive analysis shows how the distribution of interest in RMs differs according to the previously described variables. Gender and marital status do not seem to have an effect (Figure 1), while respondents in the lowest quintile of housing wealth appear more interested (Figure 2). Debt aversion shifts the distribution of interest towards the left (least interested), while negative retirement expectations shift it towards the right (Figure 3 and Figure 4); answering all financial literacy tests correctly does not seem to affect the distribution of interest in RMs (Figure 5)

\subsection{Econometric specifications}

As we have highlighted already, the UCS oversamples the wealthy, and restricts participation to clients with at least 10,000 euros in deposits ${ }^{21}$. Furthermore, only homeowners who answered the RM-related question are included in the regression, which might reduce the scope for our estimates.

\footnotetext{
${ }^{21}$ We have to assume that interest in RMs and the truncation factor (having more than 10,000 euros in deposits) are not correlated. This may or may not sound plausible, however the results will show that subjective states, rather than objective circumstances, appear more significantly correlated with our dependent variable.
} 
The reason we are using the UCS rather than the more representative SHIW is that, to our knowledge, it is the only survey in Italy that includes a specific question on RMs. Bearing in mind such limitations, we can further our analysis and investigate the determinant of interest in RMs.

The respondent's interest in RMs is measured on an ordinal scale, and the levels of interest are represented by a discrete variable that can take one of the following five values:

$y_{i}=1$ if the respondent is not interested

$y_{i}=2$ if the respondent is barely interested

$y_{i}=3$ if the respondent is somewhat interested

$y_{i}=4$ if the respondent is quite interested

$y_{i}=5$ if the respondent is very interested

We assume that the discrete values are based on an underlying continuous and latent variable $y^{*}$ and that this latent variable is a linear function of all the explanatory variables:

$$
y_{i}^{*}=\boldsymbol{\beta} \boldsymbol{x}^{\prime}+\varepsilon \quad \text { for } I=1,2, \ldots, N
$$

where $\boldsymbol{\beta}$ is a vector of parameters to be estimated, $\boldsymbol{x}$ is a vector of covariates that are assumed to be strictly independent of , $N$ is the number of respondents, and is the error term, which we assume to be normally distributed.

Let $\mu_{1}<\mu_{2}<\mu_{3}<\mu_{4}$ be the unknown thresholds parameters or cut-off points.

Then we observe

$$
\begin{aligned}
& y_{i}=1 \text { if } y_{\mathrm{i}}{ }^{*} \leq \mu_{1} \\
& y_{i}=2 \text { if } \mu_{1}<y_{i}{ }^{*} \leq \mu_{2} \\
& y_{i}=3 \text { if } \mu_{2}<y_{i}{ }^{*} \leq \mu_{3}
\end{aligned}
$$




$$
\begin{aligned}
& y_{i}=4 \text { if } \mu_{3}<y_{i}{ }^{*} \leq \mu_{4} \\
& y_{i}=5 \text { if } y_{i}^{*}>\mu_{4}
\end{aligned}
$$

The threshold parameters are estimated together with the $\boldsymbol{\beta}$ values to help match the probabilities associated with each discrete outcome.

The probabilities of $y_{i}$ being classified as not interested, barely interested, somewhat interested, quite interested, and very interested, respectively, are given by

$$
\begin{aligned}
& \operatorname{Prob}\left(y_{i}=1\right)=\operatorname{Prob}\left(\boldsymbol{\beta}^{\prime} \boldsymbol{x}+\varepsilon \leq \mu_{1}\right) \\
& \operatorname{Prob}\left(y_{i}=2\right)=\operatorname{Prob}\left(\mu_{1}<\boldsymbol{\beta} \boldsymbol{x}^{\prime}+\varepsilon \leq \mu_{2}\right) \\
& \operatorname{Prob}\left(y_{i}=3\right)=\operatorname{Prob}\left(\mu_{2}<\boldsymbol{\beta} \boldsymbol{x}^{\prime} \boldsymbol{x} \leq \mu_{3}\right) \\
& \operatorname{Prob}\left(y_{i}=4\right)=\operatorname{Prob}\left(\mu_{3}<\boldsymbol{\beta} \boldsymbol{x}^{\prime} \boldsymbol{x} \leq \mu_{4}\right) \\
& \operatorname{Prob}\left(y_{i}=5\right)=\operatorname{Prob}\left(\boldsymbol{\beta}^{\prime} \boldsymbol{x}+\varepsilon>\mu_{4}\right)
\end{aligned}
$$

Both the cutoff points and $\boldsymbol{\beta}$ coefficients can be estimated as an ordered probit model by the maximum likelihood method (Greene 2003; Train 2003). Estimating the $\boldsymbol{\beta}$ values is not enough, since they do not reflect marginal changes in probability; therefore we calculate the marginal effects (at the mean value) to interpret results more clearly.

The vector of covariates $\boldsymbol{x}$ includes the following: age categories for the household head, the log of the household income, the log of average housing wealth per square metre by region and city size, a financial literacy index, a risk aversion index, and several dichotomous variables to control for heterogeneity (single/divorced, widower, female, retired, university graduate, household with or without children, negative retirement expectations, debt aversion, and willingness to sell the house). 


\subsection{Estimation results}

A rich set of sociodemographic factors, personal characteristics, and preferences has been used to capture respondents' attitudes in the ordered probit regression.

A first-order probit was carried out using only demographic and socioeconomic variables as controls (see Table 8). Most age categories are not significant, except for the over 70 s who, despite being the main potential beneficiaries, are less likely to be interested in RMs. Gender, and higher education are not significant; being single or divorced is significantly correlated with a higher level of interest; household income is not significant. Since housing wealth is potentially endogenous, we use the average housing equity per square metre by region and city size and observe that it is significantly and negatively correlated with interest in RMs. The bequest motive, proxied by having children in the household ${ }^{22}$, does not appear to predict a lower level of interest, as it is positively, albeit not significantly, correlated with interest in the product. A possible explanation is that RMs can be used to increase not only one's own consumption, but also his or her children's.

We carry out a second ordered probit regression adding respondents' attitudes as controls and find that they have higher predictive power (see Table 9), while demographics lose significance; in particular, risk aversion, perceiving the house as a risky investment and having negative expectations about future pension income are correlated with a significantly higher level of interest.

\footnotetext{
${ }^{22}$ As a robustness check we also controlled for reporting bequest as a reason for saving, and the results are not significant.
} 
We find evidence contrasting the suggestion that the desire to move from one's current home is a deterrent to entering the RM market (Kutty 1999; Caplin 2001. On the contrary, interest in RM is highly and positively correlated with the willingness to sell one's house, indicated by a binary variable equal to one if respondents claimed to be 'certainly' or 'quite probably' willing to liquidate their house (as a means of increasing income), or equal to zero if respondents were 'certainly not' or 'probably not' interested in liquidating their home.

The effect of risk aversion is estimated through an index taking on values from 0.1 to 1 (low to high risk aversion), ${ }^{23}$ the coefficient is positive and significant. The perception of risks specifically related to housing investment is captured by a binary variable awarding one point to homeowners who perceive housing investment as quite risky or very risky, and zero otherwise. As the binary variable takes the value of 1 , the probability that $\mathrm{y}=1$ ("not interested") decreases by $8.9 \%$. Uncertainty about post-retirement income is gauged by a binary variable awarding one point to respondents who claimed to be very worried or quite worried about their economic welfare in old age, and zero otherwise. Being worried about the future is associated with a significantly higher interest in $\mathrm{RMs}$, since the probability that $\mathrm{y}=1$ decreases by 7.2 percentage points.

Among the predictors of lower interest, reluctance to borrow (debt aversion) and higher average housing equity are particularly significant. As financial literacy increases, so does the probability of not being interested in the product. We checked whether different indicators of financial literacy, for

\footnotetext{
${ }^{23}$ A score of one was assigned to every positive answer to the question on risk in a gain scenario. All the answers were then summed and divided by 10 to obtain a risk loving index ranging from 0.1 to one; this was then reversed to obtain an index of risk aversion.
} 
instance the one used in Guiso and Jappelli $(2009)^{24}$, might yield different results, but the coefficient remains negative, even though the significance is slightly lower.

Further checks are carried out by selecting an older sample of respondents. If we restrict the sample size to the over 50, leaving us with a total of 747 observations, the main results do not change (table not reported, but available on request): uncertainty about post-retirement standard of living and the perception of housing investment as risky are the only significant predictors of interest; debt aversion is the most significant predictor of lack of interest, while all other variables are not significant. Moreover, splitting the sample into those who are willing and unwilling to sell their house (table not reported, but available on request) reveals that, among respondents who are more attached to their homes, being a pensioner and having negative post-retirement expectations are significant predictors of interest in the product. Note that the sample size is extremely reduced, as the percentage of household heads willing to sell their house is not very high.

Our results shed important light on the potential demand for RM: it would appear as though the product is not yet understood as a way to achieve consumption smoothing after retirement, but rather as an option in case of necessity. People with higher housing equity and the elderly appear less interested in this kind of products, even though they would receive a larger annuity. This evidence suggests that making some counselling for the elderly compulsory, for instance requiring attendance to financial literacy courses (in which people are exposed to the basic concept of asset

\footnotetext{
24 The indicator of financial literacy built by Guiso and Jappelli considers not only the 3 financial literacy tests that we used, but also a fourth one relative to portfolio diversification and the risk assessment relative to different types of financial assets and housing.
} 
decumulation and the way of accomplish it), would generate higher welfare by informing people about their consumption possibilities.

\section{Conclusions}

Understanding the prospective role of RMs is important for both micro and macroeconomic reasons: it can increase income security in old age and allow better consumption smoothing, as well as alleviate the burden of an ageing population on public budgets. This paper contributes to the task by focusing on the Italian potential market.

Since approximately $70 \%$ of the Italian households are homeowners, with housing wealth representing over $80 \%{ }^{25}$ of their assets, the availability of home equity release instruments is an important determinant of the timing and dimension of wealth depletion with old age. We estimate household head characteristics most significantly correlated with a given level of interest: being single or divorced and resident in the north of Italy, predict a higher level of interest, while being over 70 has the opposite effect. Household income is not significant. Housing equity is negatively correlated with interest in the product. Debt aversion lowers the probability of being interested in the product, while having negative post-retirement expectations predicts higher interest. The bequest motive does not emerge as a hindrance to the uptake of the product.

Three main findings emerge from our analysis: first, homeowners who are prepared to sell their home are more likely to be interested in the product, considered as an alternative to downsizing. Second, respondents perceive RMs as debt (even though the burden of repaying the loan lies with their

\footnotetext{
${ }^{25}$ Median values.
} 
heirs), and debt aversion predicts low interest. Third, homeowners who are more concerned about their standard of living after retirement are also more likely to be interested in RMs, which is consistent with both the cuts and the greater uncertainty Italian households had to endure following recent pension reforms.

We also find that RMs do not seem to be well understood products as the major potential beneficiaries appear less likely to be interested. Rather than being considered as an instrument to accomplish consumption smoothing, it is perceived as a last resort in case of poverty. This evidence strongly encourages the realisation of a well structured financial education program, particularly targeted to low income elderly. From a policy standpoint, the need to provide financial counselling to the elderly in order to make them aware of their consumption possibilities becomes a priority. 


\section{References}

Ando, A., Guiso, L., Terlizzese, D. (1993). 'Dissaving by the Elderly, Transfer Motives and Liquidity Constraints'. NBER Working Paper Series 4569.

Angelini, V., Laferrère A. (2010). 'Residential Mobility of the European Elderly'. CESifo Working Paper No. 3280.

Appleton, N. (2003) 'Ready, steady... but not quite go. Older home owners and equity release: a review.' Joseph Rowntree Foundation.

Bank of Italy (2010) 'I bilanci delle famiglie Italiane'. Supplemento al bollettino statistico indagini campionarie.

Caplin, A. (2000). 'Inertia in the U.S. Housing Finance Market: Cases and Causes'. Paper prepared for the joint AEA/AREUEA session, New Orleans, New York University.

Caplin, A. (2001). 'The Reverse Mortgage Market: Problems and Prospects'. In Innovations in Housing Finance for the Elderly, Pension Research Council. Olivia Mitchell, ed. Pension Research Council.

Carroll, C., Hall, R., Zeldes, S. (1992): 'The Buffer Stock Theory of Saving: Some Macroeconomic Evidence'. Brookings Papers on Economic Activity, Vol. 1992, No. 2, 61156.

Case, B., Schnare, A. (1994). 'Preliminary Evaluation of the HECM Reverse Mortgage Program'. Journal of American Real Estate and Urban Economics Association, Vol. 22, No. 2, pp. 301-346.

Chiuri, M., Jappelli, T. (2007). 'Do the Elderly Reduce Housing Equity? An International Comparison'. Centre for Studies in Economics and Finance.

Davidoff, T., Welke, G. (2005). 'Selection and Moral Hazard in the Reverse Mortgage Market'. Mimeo, University of California, Berkeley.

Duca, J., Kumar, A. (2010). 'Financial Literacy and Mortgage Equity Withdrawals'. Research Department, Federal Reserve Bank of Dallas, Dallas, TX.

Eschtruth, A., Tran, L. (2001). 'A Primer on Reverse Mortgage'. Center for Retirement Research, Boston College.

Fornero, E., Monticone, C. (2010). 'Financial Literacy and Pension Plan Participation in Italy'. Preliminary draft, presented at Financial Literacy around the World (FLat world), Collegio Carlo Alberto, 20-21 Dec 2010. Torino.

Greene, William H. (1993). 'Econometric Analysis'. Fourth edition. Prentice Hall, Upper Saddle Rive (NJ).

Gibler, K., Rabianski, J. (1993). 'Elderly Interest in Home Equity Conversion'. Housing Policy Debate, Vol. 4, No. 4, Fannie Mae.

Guiso, L., Jappelli, T. (2009). 'Financial Literacy and Portfolio Diversification'. Centre for Studies in Economics and Finance, Working Paper No. 212.

Hancook, R. (1998). 'Can Housing Wealth Alleviate Poverty among Britain's Older Population?' Fiscal Studies, 19: 249-272 
Kahneman, D., Tversky, A., (1991). "Loss Aversion in Riskless choice: a ReferenceDependent Model", Quarterly Journal of Economics. Vol. 106, pp 1039 - 1061.

Kotlikoff, L., Summers, L. (1981). 'The Role of Intergenerational Transfers in Aggregate Capital Accumulation', Journal of Political Economy, Vol. 89, No. 4, pp. 706-732

Kutty, N. (1999) 'Demographic Profiles of Elderly Homeowners in Poverty Who Can Gain from Reverse Mortgages', April, mimeo.

Leviton, R. (2002). 'Reverse Mortgage Decision-Making'. Journal of Aging and Social Policy, Vol. 13, No. 4, 1-16.

Lusardi, A., Mitchell, O. (2006). 'Baby Boomer Retirement Security: The Roles of Planning, Financial Literacy, and Housing Wealth'. Journal of Monetary Economics, Volume 54, Issue 1, January 2007, Pages 205-224.

Mayer J., Simons K. (1993). 'Reverse Mortgages and the Liquidity of Housing Wealth'. Working Paper No. 93-5, Federal Reserve Bank of Boston.

Mitchell, O., Piggott, J. (2003). "Final Report: Unlocking Housing Equity in Japan", Economic and Social Research Institute, Cabinet Office, Government of Japan.

Modigliani, F., Brumberg, R. (1954) 'Utility analysis and the consumption function: an interpretation of cross-section data' in Kenneth K. Kurihara, ed., Post-Keynesian Economics, New Brunswick, NJ. Rutgers University Press. Pp 388-436.

Ong, R. (2008).'Unlocking Housing Equity through Reverse Mortgages: The Case of Elderly Homeowners in Australia'. International Journal of Housing Policy, Vol. 8, No. 1, 61-79.

Reed, R. (2009). 'The Increasing Use of Reverse Mortgages by Older Households'. Working paper, Deakin University.

Reifner, U., Clerc-Renaud, S., Pérez-Carrillo, E., Tiffe, A., Knobloch, M (2009). 'Study on Equity Release Schemes in the EU'. Institut für Finanzdienstleistungen e.V.

Rodda, D. T., Herbert, C., Lam, K. (2000). 'Evaluation Report of FHA's Home Equity Conversion Mortgage Insurance Demonstration'. Final Report, Department of Housing and Urban Development, Washington, DC.

Shan, H. (2009). 'Reversing the Trend: The Recent Expansion of the Reverse Mortgage Market'. Finance and Economics Discussion Series 2009-42, Federal Reserve Board, Washington, DC.

Skinner, J., Zeldes, S. (2002). "The Importance of Bequests and Life-Cycle Saving in Capital Accumulation: A New Answer", American Economic Association, vol. 92(2), pages 274278.

Train, K. (2003). 'Discrete Choice Method with Simulation'. Cambridge University Press, Cambridge.

Venti, S., Wise, D. (1987). 'Aging Moving and Housing Wealth'. NBER Working Paper 2324.

Williams, P. (2008). 'Please release me! A review of the equity release market in the UK, its potential and consumer expectations'. Council of Mortgage Lenders Research. 


\title{
Appendix. Survey questions used to construct the control variables
}

\author{
Risk aversion
}

Gain - Imagine you are in a room from which you can exit through two doors: If you choose the correct one, you win $€ 10,000$; if you choose the wrong one, you win nothing. Of course, you don't know where the prize is. You can also choose a back door and withdraw a fixed amount. Answer: Yes/no.

- If I offered €100, would you give up choosing between the two doors and settle for the back door? (Continue to the next question if no.) And if I offered €500? And if I offered $€ 1,500$ ? [...] And if I offered $€ 9,000$ ?

Loss - Imagine now a more difficult situation. You can still exit the room through two doors, however if you choose the correct one, you win nothing, but if you choose the wrong one, you lose $€ 10,000$. You may also choose a third door and lose a fixed amount.

- Would you pay $€ 9,000$ to exit through the backdoor? (Continue to the next if she says No)

\section{Debt aversion}

What is your opinion about borrowing? (select one answer)

a) I have no qualms/impediments to using loans should I need to (10.5\%); b) I am willing to resort only to limited borrowing, since I would rather not encumber my future with excessive burdens $(18.9 \%)$; c) I would rather not have debts $(70.6 \%)$.

Financial literacy: The respondent is awarded one point for answering correctly.

Inflation - money illusion.

Suppose a bank account yields a $2 \%$ interest per annum (after expenses and taxes). If actual inflation is $2 \%$ per year (assuming you did not access your account) after two years, the amount deposited can buy you (select one answer):

a) More than it can buy today; b) less than it can buy today; c) the same as it can buy today (correct); and d) cannot answer/cannot understand.

Interest rates

Imagine having a 'tip' and knowing for certain that in six months interest rates will rise. Do you think it is appropriate to purchase fixed rate bonds today?

a) Yes; b) no (correct); c) I do not know.

\section{Diversification}

In relation to investments, people often talk about diversification. In your opinion, to have proper diversification of one's investments means (select one response):

a) To have in one's investment portfolio bonds and shares; b) not to invest for too long in the same financial product; c) to invest in the greatest possible number of financial products; d) to invest simultaneously in multiple financial products to limit exposure to the risks associated with individual products (correct); e) to not invest in high-risk instruments; f) I do not know/cannot understand.

Post-retirement expectations - select one answer

How worried are you about your economic well-being in old age/after you retire?

1. Not worried; 2 . barely worried; 3 . quite worried; 4 . very worried. 

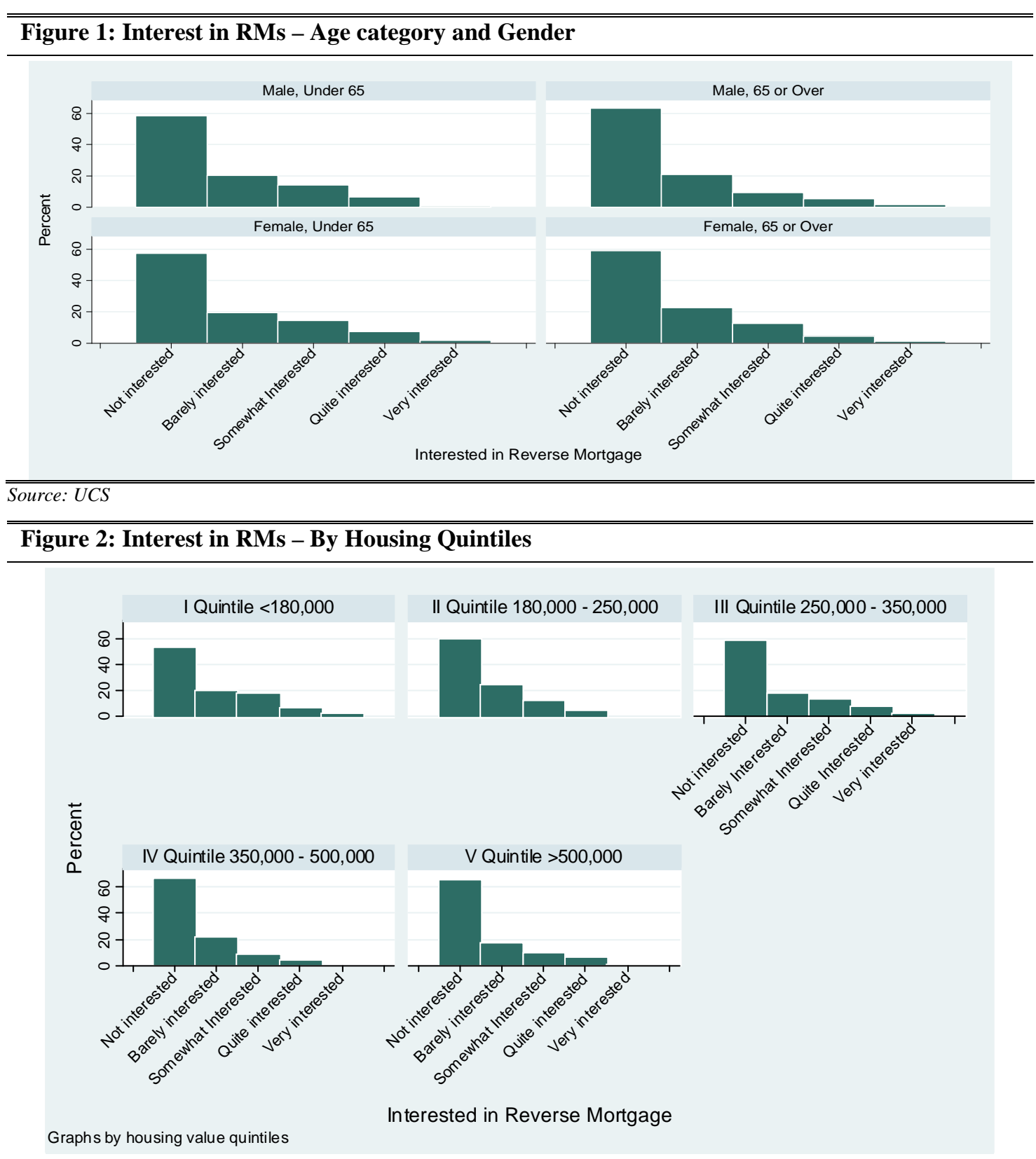

Source: UCS

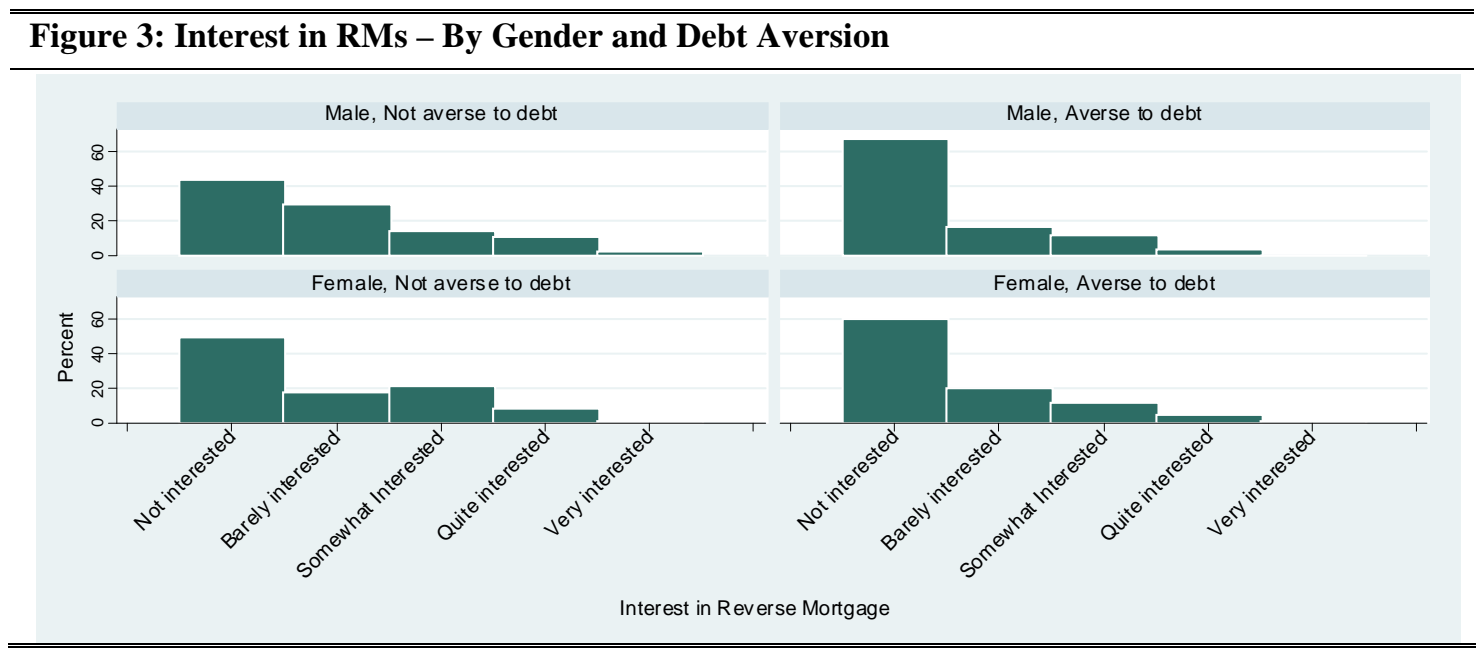

Source: UCS 


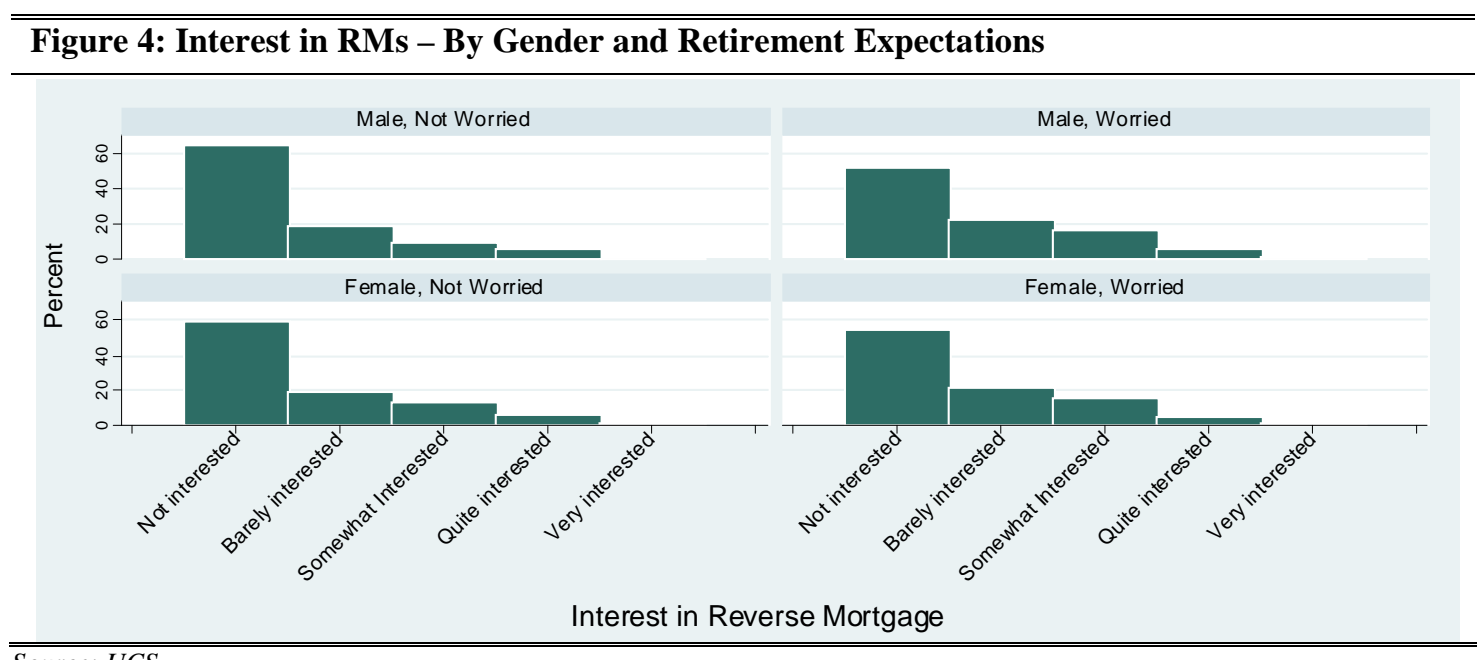

Source: UCS.

Figure 5: Interest in RMs - By Gender and Financial Literacy

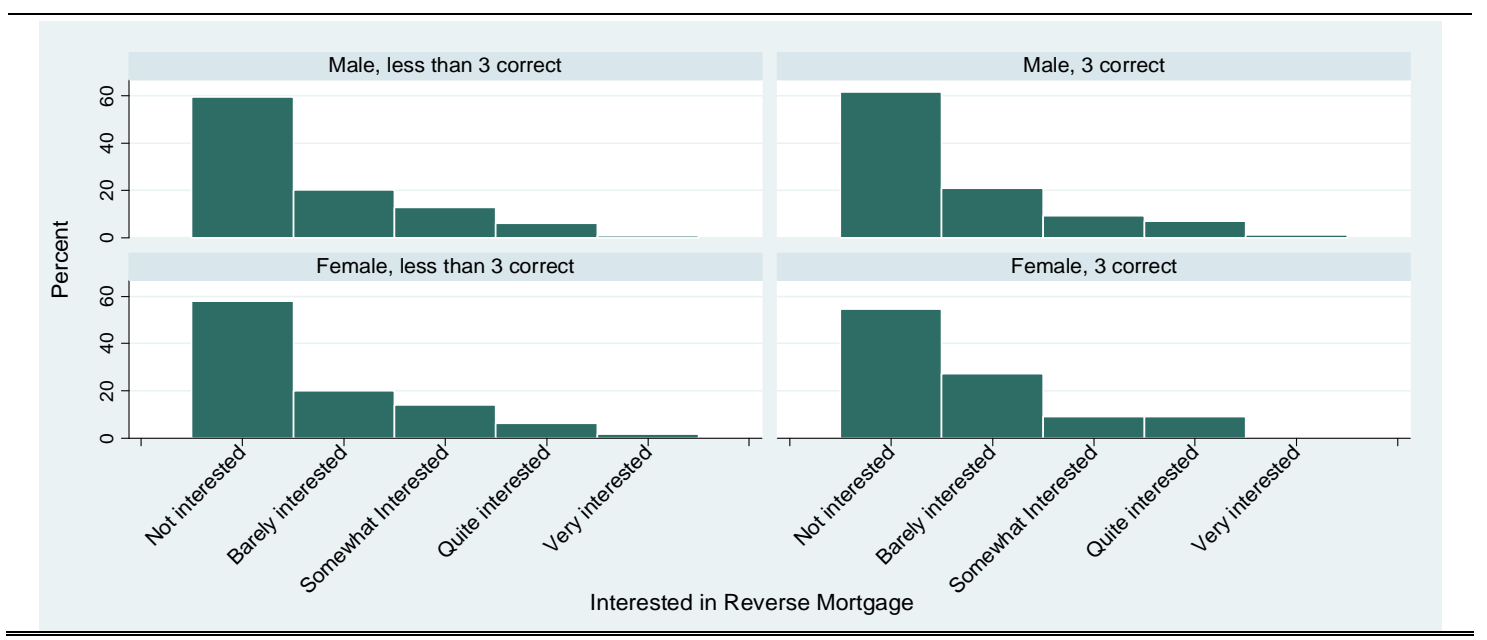


Table 1: Summary statistics

\begin{tabular}{|c|c|c|c|}
\hline Variable & Description & Mean & Std. Dev. \\
\hline \multicolumn{4}{|l|}{ Age groups } \\
\hline 41 to 50 & $=1$ if age $>40$ & 0.21 & 0.41 \\
\hline 51 to 60 & $=1$ if $51>$ age $>=60$ & 0.26 & 0.44 \\
\hline 61 to 70 & $=1$ if $61>$ age $>=70$ & 0.31 & 0.46 \\
\hline Over 70 & $=1$ if age $>70$ & 0.10 & 0.30 \\
\hline Single or divorced & $=1$ if household head is single or divorced & 0.21 & 0.40 \\
\hline Widower & $=1$ if household head is widower (male) & 0.08 & 0.27 \\
\hline Female & $=1$ if household head is Female & 0.22 & 0.41 \\
\hline High education $(d)$ & $=1$ if household head has at least a degree & 0.65 & 0.48 \\
\hline Households with children (d) & $=1$ if there are children in the household & 0.49 & 0.50 \\
\hline Householder pensioner (d) & $=1$ if household head is a pensioner & 0.35 & 0.48 \\
\hline Log Household Income & $=$ natural logarithm of Household income & 10.77 & 0.58 \\
\hline Log of housing value & $=$ natural logarithm of housing value & 7.92 & 0.35 \\
\hline Financial Literacy & $=$ index of Financial literacy, from 0 to 3 & 1.26 & 0.86 \\
\hline Risk attitude & $=$ index of risk attitude from 0.1 to 1 & 0.59 & 0.30 \\
\hline Housing risk & $=1$ if housing assets perceived as risky & 0.10 & 0.30 \\
\hline Willingness to sell the house & $\begin{array}{l}=1 \text { if household head would sell the house as a mean to increase } \\
\text { consumption in old age }\end{array}$ & 0.20 & 0.40 \\
\hline Debt averse & $=1$ if household head prefers not to have any debt & 0.71 & 0.46 \\
\hline $\begin{array}{l}\text { Negative retirement } \\
\text { expectations }\end{array}$ & $=1$ if household head is worried about future income after retirement & 0.38 & 0.49 \\
\hline
\end{tabular}

Table 2: Estimating the monetary value of RMs

\section{All}

Housing equity quintile

I quintile

II quintile

III quintile

IV quintile

V quintile

Age Category

$65-69$ years

$70-74$ years

$75-80$ years

80 years or over

Household Income Unit

Couple

Single male

Single female

Geographical Area

North

Centre

South

Source: UCS

Note: sample is restricted to the over 65.

\begin{tabular}{ccccc}
$\begin{array}{c}\text { Average } \\
\text { housing } \\
\text { equity }\end{array}$ & $\begin{array}{c}\text { Maximum } \\
\text { loan } \\
\text { advance }\end{array}$ & $\begin{array}{c}\text { RM } \\
\text { annuity }\end{array}$ & $\begin{array}{c}\text { Average } \\
\text { household } \\
\text { income }\end{array}$ & $\begin{array}{c}\text { Percentage } \\
\text { gain in income } \\
\text { from RM }\end{array}$ \\
\hline 376,613 & 112,984 & 3,870 & 54,547 & $7 \%$ \\
& & & & \\
114,463 & 28,616 & 1,176 & 41,416 & $3 \%$ \\
199,098 & 49,775 & 2,046 & 44,533 & $5 \%$ \\
279,277 & 69,819 & 2,870 & 47,298 & $6 \%$ \\
395,139 & 98,785 & 4,060 & 62,461 & $6 \%$ \\
774,065 & 193,516 & 7,953 & 70,997 & $\mathbf{1 1 \%}$ \\
& & & & \\
414,130 & 93,179 & 4,255 & 55,948 & $8 \%$ \\
422,360 & 137,267 & 6,986 & 53,219 & $13 \%$ \\
339,500 & 127,313 & 8,680 & 42,738 & $20 \%$ \\
433,333 & 173,333 & 11,080 & 44,180 & $\mathbf{2 5 \%}$ \\
& & & & \\
420,668 & 105,167 & 4,322 & 58,848 & $7 \%$ \\
330,083 & 82,521 & 3,392 & 53,618 & $6 \%$ \\
362,876 & 90,719 & 3,728 & 45,025 & $8 \%$ \\
& & & & $8 \%$ \\
394,763 & 98,691 & 4,056 & 53,657 & $8 \%$ \\
445,478 & 111,370 & 4,577 & 56,260 & \\
432,618 & 108,154 & 4,445 & 55,099 & $8 \%$ \\
\hline
\end{tabular}

.

$=1$ if age $>40$

ingle or divorced

if household head is Female

$=1$ if household head prefers not to have any deb

0.38

.27

41

50

48

35

86

30 
Table 3: Comparing UCS and SHIW

\begin{tabular}{lrr}
\hline \hline & UCS & SHIW \\
\cline { 2 - 3 } Age of household head & 56.0 & 57.6 \\
Female household heads & $22.0 \%$ & $37.0 \%$ \\
Elderly household heads & $29.6 \%$ & $36.3 \%$ \\
Higher education (degree or more) & $32.4 \%$ & $8.9 \%$ \\
Pensioners & $29.4 \%$ & $36.1 \%$ \\
Self-employed & $90.3 \%$ & $10.2 \%$ \\
Homeowners & $€ 71,325$ & $71.2 \%$ \\
Average household income & $€ 376,613$ & $€ 31,893$ \\
Average housing equity & 1,686 & $€ 235,294$ \\
\# of observations & & 7,768 \\
\hline \hline Source: UCS and SHIW & & \\
(a) Unfinished years of education are added to the level attained immediately before. & & \\
(b) Includes housewives and the voluntarily unemployed. &
\end{tabular}

Table 4: Summary statistics by income level and distribution

\begin{tabular}{|c|c|c|c|c|}
\hline \multirow{2}{*}{$\begin{array}{l}\text { Percentile } \\
\text { In } €\end{array}$} & \multicolumn{2}{|c|}{ UniCredit } & \multicolumn{2}{|c|}{ SHIW } \\
\hline & $\begin{array}{l}\text { Household net } \\
\text { disposable income }\end{array}$ & $\begin{array}{c}\text { Individual net } \\
\text { disposable income }\end{array}$ & $\begin{array}{c}\text { Household net } \\
\text { disposable income }\end{array}$ & $\begin{array}{c}\text { Individual net } \\
\text { disposable income }\end{array}$ \\
\hline $5^{\text {th }}$ & 17,934 & 9,500 & 9,078 & 3,767 \\
\hline $10^{\text {th }}$ & 22,000 & 13,883 & 11,968 & 5,562 \\
\hline $25^{\text {th }}$ & 31,733 & 20,000 & 17,169 & 10,000 \\
\hline $50^{\text {th }}$ & 48,393 & 31,000 & 26,217 & 15,349 \\
\hline $75^{\text {th }}$ & 76,655 & 55,000 & 39,766 & 22,487 \\
\hline $90^{\text {th }}$ & 129,600 & 100,000 & 55,823 & 32,000 \\
\hline $95^{\text {th }}$ & 195,827 & 150,239 & 69,275 & 41,294 \\
\hline Mean & 71,325 & $\mathbf{5 0 , 7 1 7}$ & 31,893 & 18,450 \\
\hline Standard deviation & 86,024 & 67,847 & 27,276 & 18,578 \\
\hline \# of observations & 1,686 & 1,686 & 7,768 & 13,428 \\
\hline
\end{tabular}

Source: UCS and SHIW

Table 5: Summary statistics by housing wealth level and distribution

\begin{tabular}{|c|c|c|c|c|}
\hline \multirow{2}{*}{$\begin{array}{l}\text { Percentile } \\
\text { In } €\end{array}$} & \multicolumn{2}{|c|}{ UniCredit } & \multicolumn{2}{|c|}{ SHIW } \\
\hline & $\begin{array}{c}\text { Household housing } \\
\text { wealth }\end{array}$ & $\begin{array}{l}\text { Housing wealth per } \\
\text { square metre }\end{array}$ & $\begin{array}{l}\text { Household housing } \\
\text { wealth }\end{array}$ & $\begin{array}{c}\text { Housing wealth per } \\
\text { square metre }\end{array}$ \\
\hline $5^{\text {th }}$ & 100,000 & $1,000.0$ & 50,000 & 666.7 \\
\hline $10^{\text {th }}$ & 140,000 & $1,307.7$ & 80,000 & 892.9 \\
\hline $25^{\text {th }}$ & 200,000 & $1,829.3$ & 125,000 & $1,307.7$ \\
\hline $50^{\text {th }}$ & 300,000 & $2,500.0$ & 200,000 & $1,875.0$ \\
\hline $75^{\text {th }}$ & 450,000 & $3,571.4$ & 300,000 & $2,560.0$ \\
\hline $90^{\text {th }}$ & 700,000 & $5,000.0$ & 400,000 & $3,529.4$ \\
\hline $95^{\text {th }}$ & 900,000 & $6,315.8$ & 500,000 & $4,285.7$ \\
\hline Mean & 376,613 & $2,932.1$ & 235,294 & $2,095.9$ \\
\hline Standard deviation & 313,963 & $1,753.4$ & 201,493 & $1,196.1$ \\
\hline \# of observations & 1,324 & 1,323 & 5,474 & 13,428 \\
\hline
\end{tabular}


Table 6: Financial literacy

\begin{tabular}{|c|c|c|c|c|c|}
\hline \multirow{2}{*}{$\begin{array}{l}\text { Financial Literacy } \\
\text { (\% of correct answers) }\end{array}$} & \multicolumn{2}{|c|}{ Under 65} & \multicolumn{2}{|c|}{ Over 65} & \multirow[b]{2}{*}{ All } \\
\hline & Male & Female & Male & Female & \\
\hline No correct answers & 18.8 & 21.8 & 21.8 & 23.8 & 20.2 \\
\hline 1 correct answer & 39.3 & 43.6 & 39.1 & 53.3 & 40.8 \\
\hline 2 correct answers & 33.1 & 29.3 & 32.0 & 21.0 & 31.2 \\
\hline 3 correct answers & 8.8 & 5.3 & 7.1 & 1.9 & 7.4 \\
\hline \# of observations & 921 & 266 & 394 & 105 & 1,686 \\
\hline
\end{tabular}

Table 7: Distribution of housing wealth and household income by gender and age group

\begin{tabular}{|c|c|c|c|c|}
\hline & \multicolumn{2}{|c|}{ Average Housing value } & \multicolumn{2}{|c|}{ Average Household Income } \\
\hline & Male & Female & Male & Female \\
\hline Under 40 & 306,674 & 384,546 & 56,711 & 68,227 \\
\hline 41 to 50 & 368,211 & 300,846 & 75,243 & 61,266 \\
\hline 51 to 60 & 364,785 & 333,781 & 80,040 & 60,388 \\
\hline 61 to 70 & 424,006 & 390,121 & 84,452 & 47,532 \\
\hline Over 70 & 438,963 & 361,786 & 63,717 & 44,142 \\
\hline
\end{tabular}


Table 8: Ordered probit regression, controlling for demographics only

\begin{tabular}{|c|c|c|c|c|c|c|}
\hline \multirow[b]{2}{*}{ Interested in RMs } & \multirow[b]{2}{*}{ Coeff. } & \multicolumn{5}{|c|}{ Marginal Effects on Probabilities } \\
\hline & & $\begin{array}{l}Y=1 \\
(\mathrm{No})\end{array}$ & $\begin{array}{c}Y=2 \\
\text { (Barely) }\end{array}$ & $\begin{array}{c}\mathrm{Y}=3 \\
\text { (Somewhat) }\end{array}$ & $\begin{array}{c}Y=4 \\
\text { (Quite) }\end{array}$ & $\begin{array}{c}Y=5 \\
(\text { Very })\end{array}$ \\
\hline & $\mathrm{b} / \mathrm{se}$ & $\mathrm{b} / \mathrm{se}$ & $\mathrm{b} / \mathrm{se}$ & $\mathrm{b} / \mathrm{se}$ & $\mathrm{b} / \mathrm{se}$ & $\mathrm{b} / \mathrm{se}$ \\
\hline \multicolumn{7}{|l|}{ Age groups } \\
\hline \multirow[t]{2}{*}{41 to 50} & -0.129 & 0.049 & -0.015 & -0.018 & -0.013 & -0.003 \\
\hline & $(-0.12)$ & $(-0.05)$ & $(-0.01)$ & $(-0.02)$ & $(-0.01)$ & $(0.00)$ \\
\hline \multirow[t]{2}{*}{51 to 60} & -0.184 & 0.071 & -0.021 & -0.026 & -0.018 & -0.005 \\
\hline & $(-0.12)$ & $(-0.05)$ & $(-0.01)$ & $(-0.02)$ & $(-0.01)$ & $(0.00)$ \\
\hline \multirow[t]{2}{*}{61 to 70} & -0.208 & 0.08 & -0.024 & -0.03 & -0.021 & -0.006 \\
\hline & $(-0.14)$ & $(-0.05)$ & $(-0.02)$ & $(-0.02)$ & $(-0.01)$ & $(0.00)$ \\
\hline \multirow[t]{2}{*}{ Over 71} & $-0.393 * *$ & $0.145^{* *}$ & $-0.050 * *$ & $-0.053 * *$ & $-0.034 * * *$ & $-0.008 * * *$ \\
\hline & $(-0.17)$ & $(-0.06)$ & $(-0.02)$ & $(-0.02)$ & $(-0.01)$ & $(0.00)$ \\
\hline \multirow[t]{2}{*}{ Single or divorced $(\mathrm{d})$} & $0.233 * *$ & $-0.092 * *$ & $0.023^{* * *} *$ & $0.034 * *$ & $0.027 * *$ & $0.008^{*}$ \\
\hline & $(-0.10)$ & $(-0.04)$ & $(-0.01)$ & $(-0.01)$ & $(-0.01)$ & $(0.00)$ \\
\hline \multirow[t]{2}{*}{ Widower (d) } & 0.116 & -0.045 & 0.012 & 0.017 & 0.013 & 0.004 \\
\hline & $(-0.14)$ & $(-0.06)$ & $(-0.01)$ & $(-0.02)$ & $(-0.02)$ & $(-0.01)$ \\
\hline \multirow[t]{2}{*}{ Female (d) } & -0.007 & 0.003 & -0.001 & -0.001 & -0.001 & 0 \\
\hline & $(-0.09)$ & $(-0.04)$ & $(-0.01)$ & $(-0.01)$ & $(-0.01)$ & $(0.00)$ \\
\hline \multirow[t]{2}{*}{ High education (d) } & -0.057 & 0.022 & -0.006 & -0.008 & -0.006 & -0.002 \\
\hline & $(-0.08)$ & $(-0.03)$ & $(-0.01)$ & $(-0.01)$ & $(-0.01)$ & $(0.00)$ \\
\hline \multirow[t]{2}{*}{ Households with children (d) } & 0.048 & -0.019 & 0.005 & 0.007 & 0.005 & 0.001 \\
\hline & $(-0.08)$ & $(-0.03)$ & $(-0.01)$ & $(-0.01)$ & $(-0.01)$ & $(0.00)$ \\
\hline \multirow[t]{2}{*}{ Householder pensioner (d) } & -0.012 & 0.005 & -0.001 & -0.002 & -0.001 & 0 \\
\hline & $(-0.10)$ & $(-0.04)$ & $(-0.01)$ & $(-0.01)$ & $(-0.01)$ & $(0.00)$ \\
\hline \multirow[t]{2}{*}{ Log Household Income } & 0.072 & -0.028 & 0.008 & 0.01 & 0.008 & 0.002 \\
\hline & $(-0.07)$ & $(-0.03)$ & $(-0.01)$ & $(-0.01)$ & $(-0.01)$ & $(0.00)$ \\
\hline \multirow{2}{*}{$\begin{array}{l}\text { Log of Avg. Housing Value } \\
\text { (by region and city size) }\end{array}$} & $-0.229 * *$ & $0.089 * *$ & $-0.025^{* *}$ & $-0.033 * *$ & $-0.024 * *$ & $-0.007 * *$ \\
\hline & $(-0.10)$ & $(-0.04)$ & $(-0.01)$ & $(-0.01)$ & $(-0.01)$ & $(0.00)$ \\
\hline Number of observations & 1,157 & & & & & \\
\hline Log likelihood & $-1,313.58$ & & & & & \\
\hline Pseudo $\mathrm{R}^{2}$ & 0.009 & & & & & \\
\hline
\end{tabular}


Table 9: Ordered probit regression, controlling for demographics and attitudes

\begin{tabular}{|c|c|c|c|c|c|c|}
\hline \multirow[b]{2}{*}{ Interested in RMs } & \multirow[b]{2}{*}{ Coeff. } & \multicolumn{5}{|c|}{ Marginal Effects on Probabilities } \\
\hline & & $\begin{array}{l}Y=1 \\
\text { (No) }\end{array}$ & $\begin{array}{c}\mathbf{Y}=\mathbf{2} \\
\text { (Barely) }\end{array}$ & $\begin{array}{c}\mathbf{Y}=\mathbf{3} \\
\text { (Somewhat) }\end{array}$ & $\begin{array}{c}Y=4 \\
\text { (Quite) }\end{array}$ & $\begin{array}{c}\mathbf{Y}=\mathbf{5} \\
(\text { Very })\end{array}$ \\
\hline & $\mathrm{b} / \mathrm{se}$ & $\mathrm{b} / \mathrm{se}$ & $\mathrm{b} / \mathrm{se}$ & $\mathrm{b} / \mathrm{se}$ & $\mathrm{b} / \mathrm{se}$ & $\mathrm{b} / \mathrm{se}$ \\
\hline \multicolumn{7}{|l|}{ Age groups } \\
\hline \multirow[t]{2}{*}{41 to 50} & -0.131 & 0.050 & -0.016 & -0.020 & -0.012 & -0.002 \\
\hline & $(-0.12)$ & $(-0.05)$ & $(-0.02)$ & $(-0.02)$ & $(-0.01)$ & $(0.00)$ \\
\hline \multirow[t]{2}{*}{51 to 60} & -0.130 & 0.050 & -0.016 & -0.020 & -0.012 & -0.002 \\
\hline & $(-0.12)$ & $(-0.05)$ & $(-0.02)$ & $(-0.02)$ & $(-0.01)$ & $(0.00)$ \\
\hline \multirow[t]{2}{*}{61 to 70} & -0.089 & 0.035 & -0.011 & -0.014 & -0.008 & -0.002 \\
\hline & $(-0.14)$ & $(-0.05)$ & $(-0.02)$ & $(-0.02)$ & $(-0.01)$ & $(0.00)$ \\
\hline \multirow[t]{2}{*}{ Over 71} & -0.285 & $0.107 *$ & -0.037 & $-0.042 *$ & $-0.023 *$ & $-0.004 *$ \\
\hline & $(-0.18)$ & $(-0.06)$ & $(-0.03)$ & $(-0.02)$ & $(-0.01)$ & $(0.00)$ \\
\hline \multirow[t]{2}{*}{ Single or divorced (d) } & $0.183^{*}$ & $-0.072 *$ & $0.020 *$ & $0.029^{*}$ & 0.019 & 0.004 \\
\hline & $(-0.10)$ & $(-0.04)$ & $(-0.01)$ & $(-0.02)$ & $(-0.01)$ & $(0.00)$ \\
\hline \multirow[t]{2}{*}{ Widower (d) } & 0.020 & -0.008 & 0.002 & 0.003 & 0.002 & 0.000 \\
\hline & $(-0.15)$ & $(-0.06)$ & $(-0.02)$ & $(-0.02)$ & $(-0.01)$ & $(0.00)$ \\
\hline \multirow[t]{2}{*}{ Female (d) } & 0.057 & -0.022 & 0.007 & 0.009 & 0.006 & 0.001 \\
\hline & $(-0.10)$ & $(-0.04)$ & $(-0.01)$ & $(-0.01)$ & $(-0.01)$ & $(0.00)$ \\
\hline \multirow[t]{2}{*}{ High education (d) } & -0.008 & 0.003 & -0.001 & -0.001 & -0.001 & 0.000 \\
\hline & $(-0.08)$ & $(-0.03)$ & $(-0.01)$ & $(-0.01)$ & $(-0.01)$ & $(0.00)$ \\
\hline \multirow[t]{2}{*}{ HH with children (d) } & 0.110 & -0.043 & 0.013 & 0.017 & 0.011 & 0.002 \\
\hline & $(-0.08)$ & $(-0.03)$ & $(-0.01)$ & $(-0.01)$ & $(-0.01)$ & $(0.00)$ \\
\hline \multirow[t]{2}{*}{ Householder pensioner (d) } & 0.017 & -0.007 & 0.002 & 0.003 & 0.002 & 0.000 \\
\hline & $(-0.10)$ & $(-0.04)$ & $(-0.01)$ & $(-0.02)$ & $(-0.01)$ & $(0.00)$ \\
\hline \multirow[t]{2}{*}{ Log Household Income } & 0.025 & -0.010 & 0.003 & 0.004 & 0.002 & 0.000 \\
\hline & $(-0.07)$ & $(-0.03)$ & $(-0.01)$ & $(-0.01)$ & $(-0.01)$ & $(0.00)$ \\
\hline \multirow{3}{*}{$\begin{array}{l}\text { Log of Avg. Housing Value } \\
\text { (by region and city size) }\end{array}$} & & & & & & \\
\hline & $-0.240^{* *}$ & $0.093^{* *}$ & $-0.028^{* *}$ & $-0.037^{* *}$ & $-0.023^{* *}$ & $-0.005^{* *}$ \\
\hline & $(-0.10)$ & $(-0.04)$ & $(-0.01)$ & $(-0.02)$ & $(-0.01)$ & $(0.00)$ \\
\hline \multirow[t]{2}{*}{ Financial Literacy } & $-0.077 *$ & $0.030 *$ & $-0.009 *$ & $-0.012 *$ & $-0.007 *$ & $-0.002^{*}$ \\
\hline & $(-0.04)$ & $(-0.02)$ & $(0.00)$ & $(-0.01)$ & $(0.00)$ & $(0.00)$ \\
\hline \multirow[t]{2}{*}{ Risk aversion } & $0.211^{*}$ & $-0.082 *$ & $0.025 *$ & $0.033 *$ & $0.020 *$ & 0.004 \\
\hline & $(-0.12)$ & $(-0.05)$ & $(-0.01)$ & $(-0.02)$ & $(-0.01)$ & $(0.00)$ \\
\hline \multirow[t]{2}{*}{ Housing risk } & $0.226^{*}$ & $-0.089 *$ & $0.023 * *$ & $0.036^{*}$ & $0.025^{*}$ & 0.006 \\
\hline & $(-0.12)$ & $(-0.05)$ & $(-0.01)$ & $(-0.02)$ & $(-0.01)$ & $(0.00)$ \\
\hline \multirow[t]{2}{*}{ Willing to sell the house } & $0.663 * * *$ & $-0.259 * * *$ & $0.051 * * *$ & $0.103 * * *$ & $0.083^{* * *} *$ & $0.023 * * *$ \\
\hline & $(-0.09)$ & $(-0.03)$ & $(-0.01)$ & $(-0.01)$ & $(-0.01)$ & $(-0.01)$ \\
\hline \multirow[t]{2}{*}{ Debt Averse } & $-0.372 * * *$ & $0.146^{* * * *}$ & $-0.039 * * *$ & $-0.058 * * *$ & $-0.040 * * *$ & $-0.009 * * *$ \\
\hline & $(-0.08)$ & $(-0.03)$ & $(-0.01)$ & $(-0.01)$ & $(-0.01)$ & $(0.00)$ \\
\hline \multirow{2}{*}{$\begin{array}{l}\text { Negative retirement } \\
\text { expectations }\end{array}$} & $0.184^{* *}$ & $-0.072 * *$ & $0.021 * *$ & $0.029 * *$ & $0.018 * *$ & $0.004 * *$ \\
\hline & $(-0.07)$ & $(-0.03)$ & $(-0.01)$ & $(-0.01)$ & $(-0.01)$ & $(0.00)$ \\
\hline Number of \# of obs. & 1,157 & & & & & \\
\hline Log likelihood & $-1,240.85$ & & & & & \\
\hline Pseudo $\mathrm{R}^{2}$ & 0.05 & & & & & \\
\hline
\end{tabular}

